Agnieszka Drzymała ${ }^{1}$

Uniwersytet Łódzki

\title{
Handel żywnością między UE a Japonią
}

\section{Food Trade between the European Union and Japan}

\begin{abstract}
Synopsis. Ważnym zagadnieniem jest handel żywnością w skali świata. Jeśli chodzi o Unię Europejską to posiada ona odpowiednie zasoby wystarczające na pokrycie zapotrzebowania ludności UE na żywność, nadwyżki produkcji własnej może eksportować i wymieniać na inne produkty bądź usługi z innymi krajami. Natomiast egzotyczny dla Europejczyków azjatycki kraj, jakim jest Japonia wydaje się nie być istotnym partnerem pod względem wymiany handlowej żywnością. Celem opracowania jest zaprezentowanie dokładnej analizy wielkości eksportu i importu żywności według nomenklatury SITC oraz HS oraz perspektyw rozwoju wzajemnej współpracy między Unią Europejską a Japonią.
\end{abstract}

Słowa kluczowe: współpraca gospodarcza, handel, żywność, Japonia, Unia Europejska

\begin{abstract}
Food trade is an important element of the global economy. As far as the European Union is concerned, it has sufficient resources to cover the EU population's demand for food, and it can export and exchange its own excess production for other products or services with other countries. However, Japan does not appear to be a significant partner in terms of food imports and exports. The aim of the study is to present a detailed analysis of the volume of food exports and imports according to the SITC and HS nomenclature and the perspectives for the development of mutual cooperation between the European Union and Japan.
\end{abstract}

Key words: economic cooperation, trade, food, Japan, EU

JEL Classification: Q17, P45, F14

\section{Wprowadzenie}

Współcześnie uważa się, że zapewnienie bezpieczeństwa żywnościowego jest jednym z najważniejszych czynników przetrwania ludzkości. Kraje UE czynnie uczestniczą, obok instytucji i organizacji międzynarodowych, w tworzeniu ram i wytycznych w tym obszarze. Są aktywnymi podmiotami w skali świata o istotnej sile wpływu na zmiany zachodzące w innych gospodarkach. Są również inspiratorami nowych metod realizacji celów żywnościowych (Barcz, Kawecka-Wyrzykowska, Michałowska-Gorywoda, 2016). Dlatego tak ważnym zagadnieniem jest wymiana handlowa. Z drugiej strony gospodarka Japonii bardzo silnie była i nadal jest uzależniona od eksportu (Wawrzyński, 2013). Ponadto każdy kraj powiększając swój udział w rynkach eksportowych wzmacnia swoją pozycję konkurencyjną (Misala, 2011), na czym zależy obu stronom. Jednak z punktu widzenia Japonii, UE stała się mniej istotnym partnerem handlowym. Dla przykładu już w 2013 roku notowany był spadek udziału UE w eksporcie ogółem Japonii do zaledwie 10\%

${ }^{1}$ dr, Katedra Gospodarki Światowej i Integracji Europejskiej, Wydział Ekonomiczno-Socjologiczny, Uniwersytet Łódzki, ul. Rewolucji 1905 r. nr 51,90-255 Łódź, e-mail: adrzymala@uni.lodz.pl 
(Pasierbiak, 2015). Powstaje zatem pytanie, czy obroty handlowe żywnością między UE a Japonią są znaczące i czy mogą mieć istotne znaczenie w przyszłości. Będące w posiadaniu UE zasoby finansowe i obszarowe umożliwiają zarówno produkcję, jak i eksport żywności. Takim przykładem handlu z innymi uczestnikami stosunków międzynarodowych jest Japonia.

Artykuł podzielony został na dwie części. W pierwszej przedstawiono obroty handlowe artykułami żywnościowymi między krajami Unii Europejskiej i Japonią. W drugiej omówiono perspektywy rozwoju wzajemnej współpracy i handlu, w tym żywnością między krajami UE a Japonią.

\section{Dane i metody}

W celu rozpoznania przyjętego problemu badawczego dokonano analizy danych urzędu Statystycznego Unii Europejskiej EUROSTAT. Zastosowano metodę analizy opisowej, wspartą prezentacją rysunków oraz metodę wnioskowania dedukcyjnego. Analizie poddano dane opisujące eksport żywności z UE do Japonii oraz import żywności do UE z Japonii. Okres badawczy obejmował lata 2013 - 2017, które pozwalają na obserwację najbardziej aktualnych danych. W tym celu wykorzystano dane zgodne $\mathrm{z}$ międzynarodową standardową klasyfikacją handlu (SITC - Standard international trade classification). W dalszej części opracowania przedstawiono dane na temat handlu żywnością między wspomnianymi stronami według sekcji zharmonizowanego systemu klasyfikacji (HS - Harmonized System). Na zakończenie zaprezentowano perspektywy wzajemnej współpracy i relacji handlowych.

\section{Obroty handlowe artykułami żywnościowymi krajów Unii Europejskiej z Japonia}

Kraje Unii Europejskiej są jednym z największych eksporterów w świecie. Handel UE ogółem z krajami świata w 2016 roku wyniósł 3452,1 mld euro, w tym z Japonią 124,5 mld euro, a w 2017 roku 3737,7 mld euro, w tym z Japonią 129,4 mld euro. Japonia była w 2016 roku szóstym głównym partnerem handlowym UE, zarówno w imporcie (66,7 mld euro), jak i w eksporcie (58,1 mld euro). W 2017 roku pozostała na tej samej pozycji, a wartości importu i eksportu wyniosły odpowiednio 68,9 mld euro i 60,5 mld euro. Szczegółowe dane dotyczące wymiany handlowej między krajami Unii Europejskiej i Japonią w latach 2006 - 2017 przedstawia rysunek 1. 


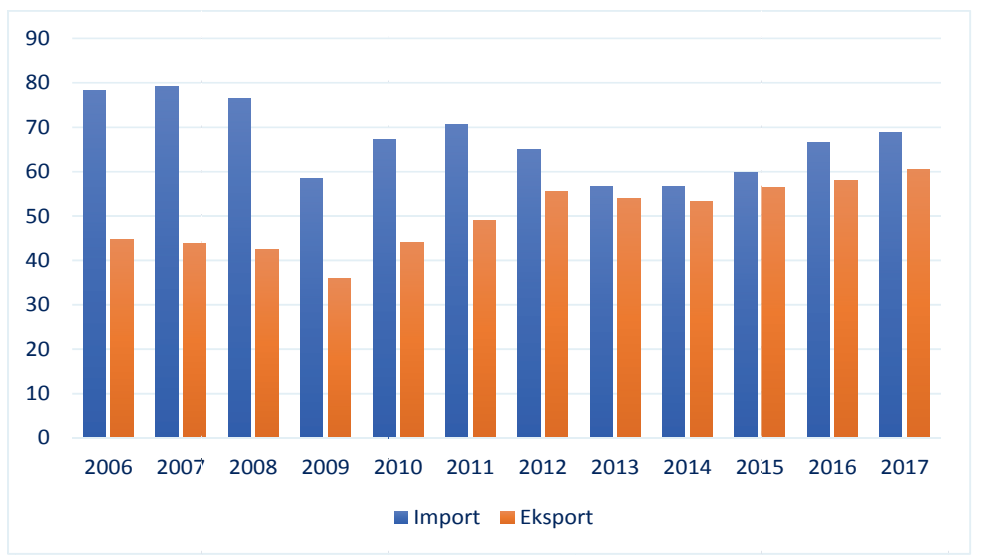

Rys. 1. Import towarów do UE z Japonii oraz eksport towarów z UE do Japonii, lata 2006-2017 (mld euro)

Fig. 1. Imports of goods to the EU from Japan and exports of goods from the EU to Japan, from 2006-2017 (EUR billion)

Źródło: opracowanie własne na podstawie: Total foods: EU Trade flows and balance; European Union, Trade in goods with Japan; Eurostat Comext, www.trade.ec.europa.eu/doclib/docs, (dostęp 24.04.2018).

Kraje posiadają różne zasoby i notowane są inne wielkości konsumpcji żywności. Zatem następuje wymiana towarów żywnościowych między poszczególnymi państwami świata. Unia Europejska jest w bardzo dobrej sytuacji pod względem produkcji i eksportu żywności. Jak wskazuje Raport Komisji Europejskiej z 18 maja 2017r. eksport produktów rolno - spożywczych z państw UE do państw spoza UE, osiagnął rekordową wartość 12,7 mld euro w marcu 2017 roku. Największy wzrost wartości eksportu unijny sektor rolno spożywczy odnotował w handlu z USA (+200 mln euro), z Japonią (+112 mln euro), Rosją (+98 mln euro) i Szwajcarią (+82 mln euro). W ciagu roku, czyli od kwietnia 2016r. do marca 2017r. wartość eksportu rolno-spożywczego w UE wyniosła 133,5 mld. Zanotowano zatem wzrost o 3,6\% w stosunku do roku poprzedniego (Aktualności..., 2017). W 2017 roku największymi importerami żywności pochodzącej z UE były takie kraje jak (Eurostat, 2018): USA (9,6 mld euro, SITC 0+1), Chiny (10 mld euro), Szwajcaria (7,5 mld euro), Japonia (5,9 mld euro) i Rosja (5,2 mld euro).

Kolejne rysunki 2 i 3, przedstawiają obroty handlowe według sekcji SITC Rev. 3 grup produktów: 1) Food - SITC codes: 0,1,22,4 oraz 2) Fish - SITC codes: 03.

Import żywności, w tym ryb z Japonii do UE w latach 2013 - 2017 przedstawia rysunek 2. Początkowo w 2013 roku importowano z Japonii żywność za 170 mln euro, w tym ryby stanowiły $28 \mathrm{mln}$ euro. Widoczny jest wzrost importu żywności, jak i ryb - trend jest rosnący do 2017 roku.

Import żywności z Japonii do UE w 2016 roku wyniósł 317 mln euro, w tym ryb 47 mln euro. W 2017 roku import ten wzrósł i wyniósł 339 mln euro, w tym ryb pozostał na niezmienionym poziomie i wynosił $47 \mathrm{mln}$ euro. Stanowiło to odpowiednio $0,5 \%$ i $0,1 \%$ importu ogółem UE z Japonii. 


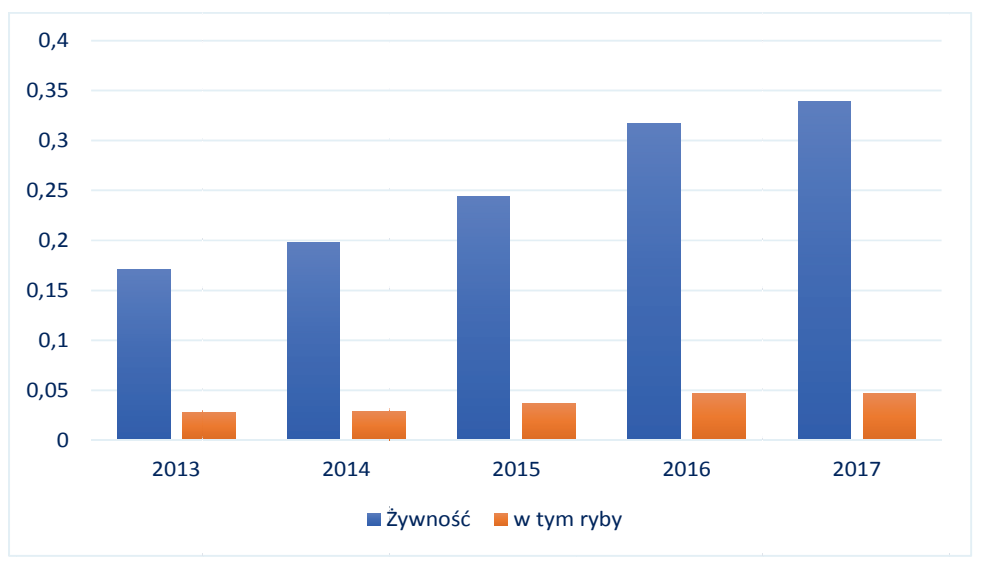

Rys. 2. Import żywności, w tym ryb z Japonii do UE zgodnie z nomenklaturą SITC (rev 3.) według grup produktów, lata 2013-2017 (mld euro)

Fig. 2. Imports of food, including fish, from Japan to the EU according to the SITC nomenclature (rev 3.) by product group, from 2013-2017 (EUR billion)

Źródło: opracowanie własne na podstawie: Trade Flows by SITC product grouping 2013 - 2016; EU, Trade with Japan; SITC Rev.3. Product Grouping;, www.trade.ec.europa.eu/doclib/docs, (dostęp 12.03.2018) oraz Trade Flows by SITC product grouping 2014 - 2017; EU, Trade with Japan; SITC Rev.3. Product Grouping;, www.trade.ec.europa.eu/doclib/docs, (dostęp 24.04.2018).

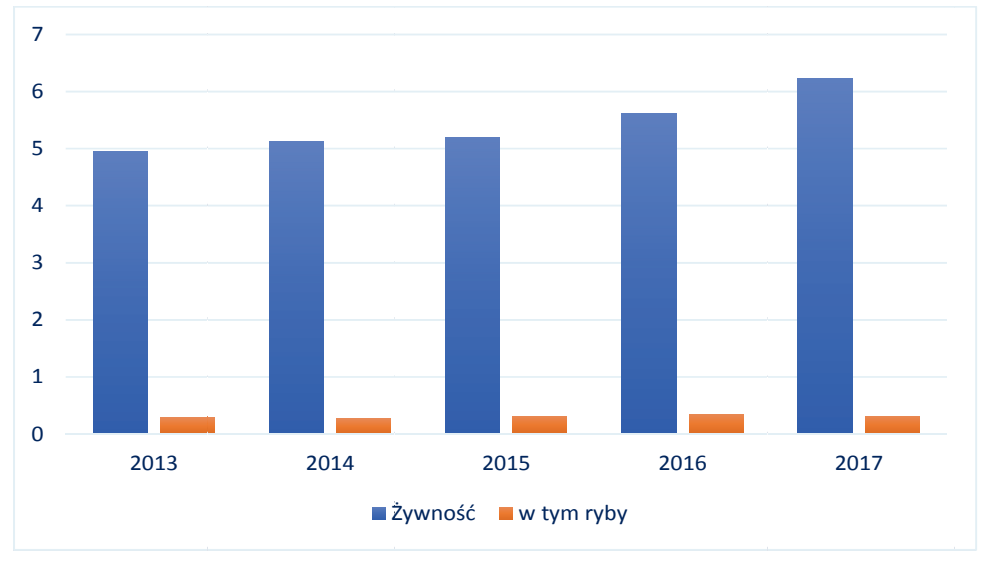

Rys. 3. Eksport żywności, w tym ryb z UE do Japonii zgodnie z nomenklaturą SITC (rev 3.) według grup produktów, lata 2013-2017 (mld euro)

Fig. 3. Exports of food, including fish, from the EU to Japan according to the SITC nomenclature (rev 3), by product group, from 2013-2017 (EUR billion)

Źródło: opracowanie własne na podstawie: Trade Flows by SITC product grouping 2013 - 2016; EU, Trade with Japan; SITC Rev.3. Product Grouping; www.trade.ec.europa.eu/doclib/docs, (dostęp 12.03.2018) oraz Trade Flows by SITC product grouping 2014 - 2017; EU, Trade with Japan; SITC Rev.3. Product Grouping;, www.trade.ec.europa.eu/doclib/docs, (dostęp 24.04.2018).

Dokładne dane na temat eksportu żywności, w tym ryb z UE do Japonii w latach 2013 - 2017 przedstawia rysunek 3. Notowany był sukcesywny wzrost eksportu żywności z UE 
do Japonii. W 2013 roku wyniósł 5 mld euro, w tym ryb 288 mln euro. Jednak eksport ryb pozostawał na względnie stałym poziomie.

Eksport żywności z UE do Japonii w 2016 roku był znacznie wyższy od importu i wyniósł 5,6 mld euro, w tym ryb $348 \mathrm{mln}$ euro. Stanowiło to odpowiednio 9,7\% i 0,6\% eksportu ogółem UE do Japonii. W 2017 roku eksport wzrósł do poziomu 6,2 mld euro, natomiast eksport ryb obniżył się do $308 \mathrm{mln}$ euro, co stanowiło $10,3 \%$ i $0,5 \%$ eksportu ogółem UE do Japonii.

Dalsza analiza oparta jest na danych Eurostat Comext, Statistical Regime 4 dotyczących obrotów handlowych według sekcji SITC w latach 2013 - 2017. Wyróżniony podział obejmuje następujące sekcje: 0 żywność i zwierzęta żywe, 1 napoje i tytoń oraz 4 oleje i tłuszcze oraz woski zwierzęce i roślinne.

Import wymienionych sekcji z Japonii do krajów UE rósł od 2013 roku do 2017 roku. UE w tym okresie importowała najwięcej towarów z sekcji 0. W 2016 roku import wyniósł odpowiednio: $0-215 \mathrm{mln}$ euro, $1-57 \mathrm{mln}$ euro, natomiast $4-36 \mathrm{mln}$ euro. Natomiast $\mathrm{w}$ 2017 roku wzrósł do poziomu: 0 -217 mln euro, 1 -66 mln euro, natomiast 4 -52 mln euro. Dane przedstawia rysunek 4.

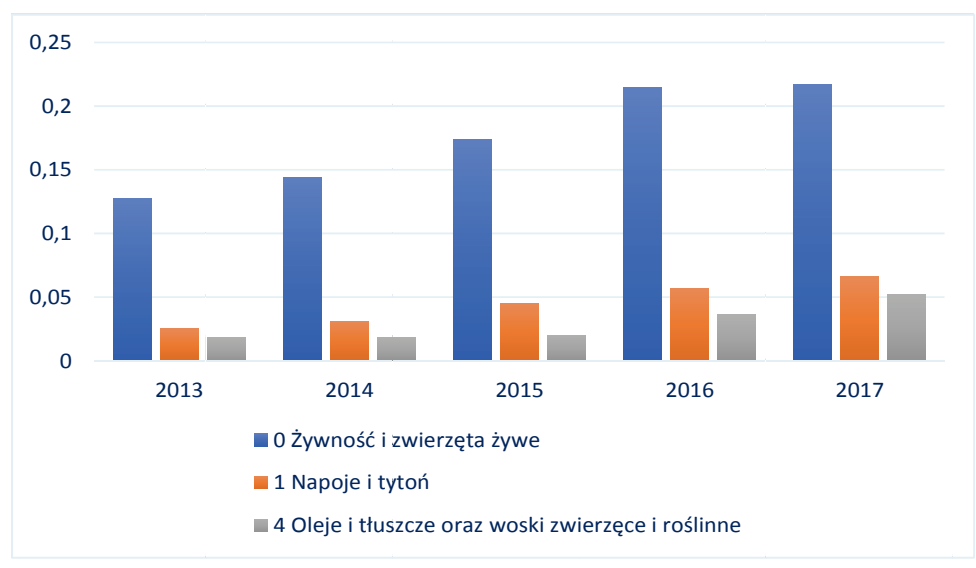

Rys. 4. Import żywności według sekcji SITC z Japonii do UE, lata 2013-2017 (mld euro)

Fig. 4. Food imports by SITC section from Japan to the EU, from 2013-2017 (EUR billion)

Źródło: opracowanie własne na podstawie: Trade Flows by SITC section 2013 - 2016; EU, Trade with Japan; www.trade.ec.europa.eu/doclib/docs, (dostęp 12.03.2018) oraz Trade Flows by SITC section 2014 - 2017; EU, Trade with Japan; www.trade.ec.europa.eu/doclib/docs, (dostęp 24.04.2018).

Kolejny rysunek 5 przedstawia eksport wymienionych sekcji z krajów UE do Japonii. UE w latach 2013 - 2017 eksportowała najwięcej towarów z sekcji 0. W 2016 roku eksport w poszczególnych sekcjach wyniósł: 0 -3,75 mld euro, $1-1,57$ mld euro, natomiast $4-287$ mln euro. W 2017 roku odpowiednio: 0 -3,96 mld euro, 1 -1,96 mld euro, 4 -305 mln euro. 


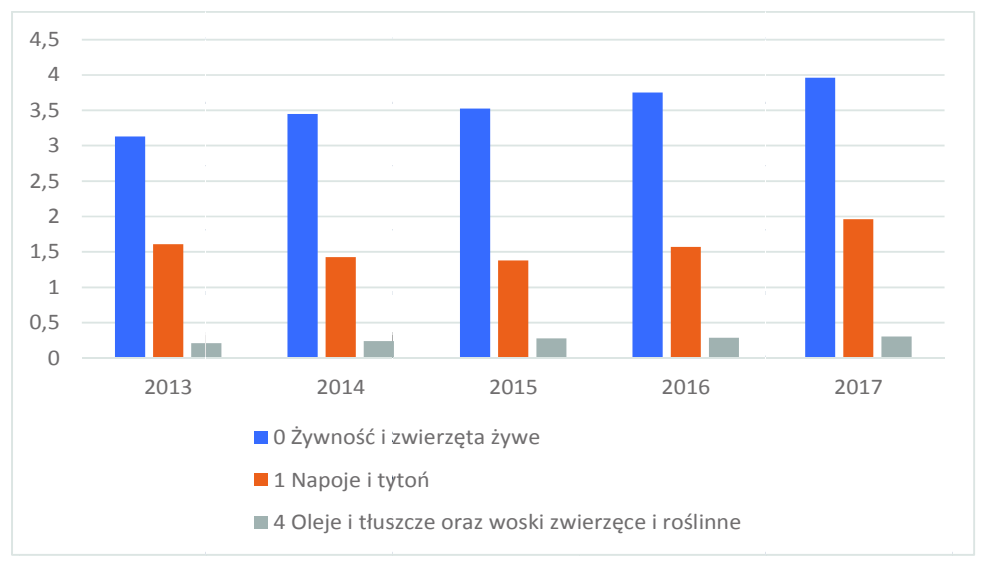

Rys. 5. Eksport żywności według sekcji SITC z UE do Japonii, lata 2013-2017 (mld euro)

Fig. 5. Food exports by SITC sections from EU to Japan, from 2013-2017 (EUR billion)

Źródło: opracowanie własne na podstawie: Trade Flows by SITC section 2013 - 2016; EU, Trade with Japan; www.trade.ec.europa.eu/doclib/docs, (dostęp 12.03.2018) oraz Trade Flows by SITC section 2014 - 2017; EU, Trade with Japan; www.trade.ec.europa.eu/doclib/docs, (dostęp 24.04.2018).

W 2016 roku żywność i zwierzęta żywe stanowiły $0,3 \%$ ogółu importu UE z Japonii oraz 6,5\% eksportu ogółem z UE do Japonii. Import tej sekcji wzrósł w 2016 roku o 23,2\%, natomiast eksport z UE o 6,4\% w stosunku do roku 2015. W 2017 roku żywność i zwierzęta żywe stanowiły również $0,3 \%$ ogółu importu UE z Japonii oraz $6,6 \%$ eksportu ogółem z UE do Japonii. Import tej kategorii wzrósł o 0,9 \%, natomiast eksport o 5,5\% w stosunku do roku 2016.

Jeśli chodzi o następną sekcję: napoje i tytoń stanowiły $0,1 \%$ ogółu importu UE z Japonii oraz 2,7\% eksportu ogółem z UE do Japonii w 2016 roku. Import ten wzrósł w 2016 roku o 2,9\% a eksport z UE o 13,8\% w stosunku do roku 2015. W 2017 roku napoje i tytoń stanowiły też $0,1 \%$ ogółu importu UE z Japonii oraz 3,2\% eksportu ogółem z UE do Japonii. Import tej kategorii wzrósł o 15,8\% a eksport o 25\% w stosunku do roku 2016.

Import kolejnej sekcji wzrósł w 2016 roku o 82,8\% a eksport z UE o 3,7\% w stosunku do roku 2015. W 2017 roku oleje i thuszcze oraz woski zwierzęce i roślinne, podobnie jak w roku 2016, stanowiły 0,1\% ogółu importu UE z Japonii oraz 0,5\% eksportu ogółem z UE do Japonii. Import tej kategorii wzrósł o 44,4\%, a eksport o 6,3\% w stosunku do roku 2016.

Kolejna analiza została przeprowadzona w oparciu o zharmonizowany system sekcji HS. Wyróżnione sekcje I, II, III i IV to w kolejności: żywe zwierzęta, produkty zwierzęce; produkty roślinne; thuszcze i oleje zwierzęce lub roślinne oraz artykuły spożywcze, napoje i tytoń. 


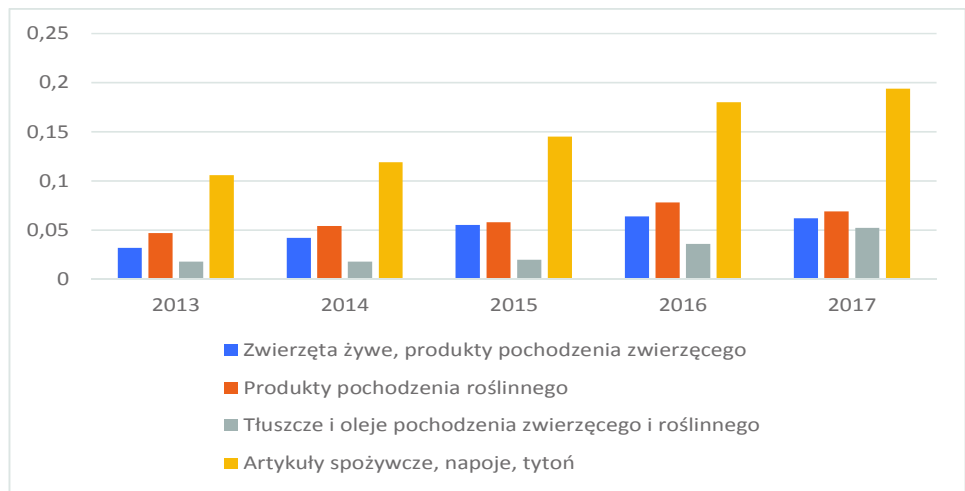

Rys. 6. Import żywności według sekcji HS z Japonii do UE, lata 2013-2017 (mld euro).

Fig. 6. Food imports by HS section from Japan to the EU, from 2013-2017 (EUR billion).

Źródło: opracowanie własne na podstawie: Trade flows by HS section 2013 -2016, EU, trade with Japan; www.trade.ec.europa.eu/doclib/docs, (dostęp 12.03.2018) oraz Trade flows by HS section 2014 -2017, EU, trade with Japan; www.trade.ec.europa.eu/doclib/docs, (dostęp 24.04.2018).

Import towarów związanych z żywnością (w każdej sekcji) z Japonii do krajów Unii Europejskiej sukcesywnie rósł od 2013 roku i był największy w 2017 roku. Na przestrzeni badanych lat UE importowała najwięcej towarów sekcji IV. W 2016 roku import wyniósł odpowiednio w sekcjach: I -63 mln euro, II - 77 mln euro, III - 36 mln euro i IV - 179 mln euro. Natomiast w 2017 roku import wyniósł: I -62 mln euro, II - 69 mln euro, III - $52 \mathrm{mln}$ euro i IV - 194 mln euro. Zarówno w 2016, jak i w 2017 roku produkty każdej z sekcji I, II i III stanowiły $0,1 \%$ importu ogółem UE, natomiast sekcji IV $0,3 \%$ importu ogółem UE. W 2017 roku zanotowano spadek importu w sekcjach: I o 1,6\% i II o 10,4\% oraz wzrost w sekcjach: III o 44,4\% i IV o 8,4\% w stosunku do roku 2016. Szczegółowe dane prezentuje rysunek 6 .

Rysunek 7 przedstawia eksport towarów związanych z żywnością, według sekcji HS z UE do Japonii w latach 2013 - 2017. Eksport rozpatrywanych towarów w sekcjach jest znacznie większy od importu. Na przestrzeni badanych lat widoczny jest wzmożony eksport towarów, zwłaszcza sekcji I, II i IV. W 2016 roku eksport w sekcjach wyniósł odpowiednio: I - 2,1 mld euro, II - $593 \mathrm{mln}$ euro, III -291 mln euro i IV - 2,8 mld euro. Odpowiadało to $3,7 \%, 1 \%, 0,5 \%$ i 4,8\% eksportu ogółem UE. Zatem w 2016 roku udział poszczególnych działów HS w handlu ogółem wzrósł. W 2017 roku eksport ten wyniósł: I 2,3 mld euro, II - 546 mln euro, III -308 mln euro i IV - 3,3 mld euro. W tym roku produkty sekcji I stanowiły 3,8\%, II 0,9\%, III 0,5\% i 5,4\% eksportu ogółem UE. W 2017 roku zanotowano spadek eksportu w sekcji II o 7,9\% oraz wzrost w sekcjach: I o 9,5\%, III o $5,8 \%$ i IV o $17,8 \%$ w stosunku do roku 2016. 


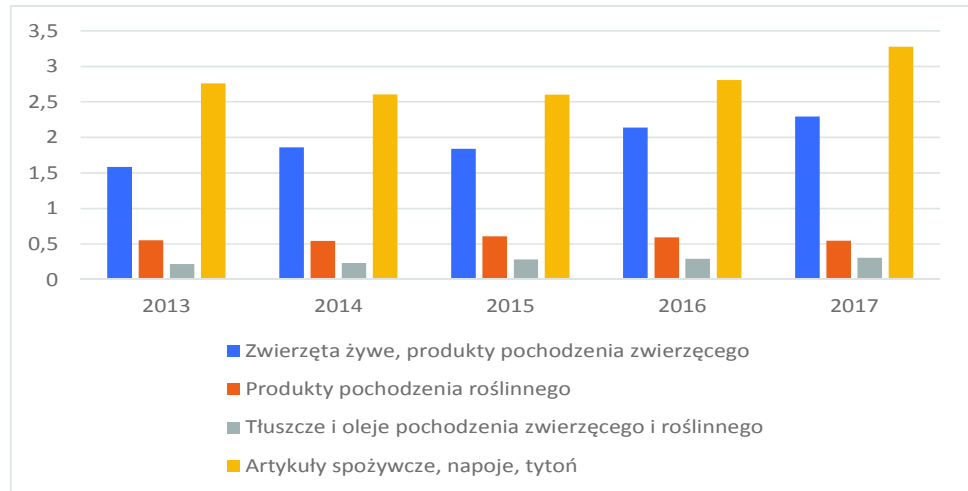

Rys. 7. Eksport żywności według sekcji HS z UE do Japonii, lata 2013-2017 (mld euro).

Fig. 7. Food exports by HS section from EU to Japan, from 2013-2017 (EUR billion).

Źródło: opracowanie własne na podstawie: Trade flows by HS section 2013 -2016, EU, trade with Japan; www.trade.ec.europa.eu/doclib/docs, (dostęp 12.03.2018) oraz Trade flows by HS section 2014 -2017, EU, trade with Japan; www.trade.ec.europa.eu/doclib/docs, (dostęp 24.04.2018).

\section{Perspektywy rozwoju współpracy i handlu, w tym żywnością między Unią Europejską a Japonią}

Japonia, mimo trwającej stagnacji gospodarczej (Grabowiecki, 2005), to aktualnie czwarta gospodarka świata o dużym popycie na żywność i produkty europejskie (Umowa..., 2018). Natomiast wspólnie z UE odpowiada za ponad jedną trzecią światowego handlu towarowego ogółem. Japonia jest szóstym partnerem handlowym Unii Europejskiej w gospodarce światowej i drugim partnerem w Azji. Komisja Europejska wskazuje, że ponad 600 tys. miejsc pracy w UE związanych jest z eksportem do Japonii (Strzępka, 2017). Obecnie Unia Europejska jest czwartym największym dostawcą produktów rolno-spożywczych do Japonii, ale przewiduje, że już wkrótce będzie pierwsza na liście pod względem eksportu wieprzowiny, serów, win i napojów spirytusowych (Rośnie..., 2017). Jednak nie jest to takie proste, bowiem dostęp do japońskiego rynku jest bardzo utrudniony. Japoński rynek rolno-spożywczy jest silnie regulowany i chroniony przed importem wysokimi cłami i barierami pozataryfowymi. Dla przykładu - średnia stosowana stawka celna na produkty rolno-spożywcze importowane $\mathrm{z}$ UE do Japonii w 2014 roku wyniosła $24,6 \%$, a tylko około $1 / 3$ produktów rolnych według linii taryfowych (a 49,9\% importu w ujęciu wartościowym) była importowana bez nałożenia ceł. Najwyższe stawki celne dotyczyły nabiału. Średnia stosowana stawka celna na nabiał wyniosła $76,3 \%$, a jedynie $9,1 \%$ importu w ujęciu wartościowym było zwolnione $\mathrm{z}$ ceł. Inne wysoko chronione grupy produktów rolno-spożywczych to: zboża i produkty zbożowe, cukier i słodycze, napoje i wyroby tytoniowe, produkty pochodzenia zwierzęcego, a także kawa i herbata. Dostęp do japońskiego rynku produktów rolno-spożywczych utrudniają także bariery o charakterze pozataryfowym, często dotyczące produktów istotnych dla eksportu unijnego, m.in. alkoholu oraz napojów bezalkoholowych czy nabiału (Mazur, 2016). 
Dlatego tak ważne są negocjacje i podpisanie wzajemnych umów gospodarczych i handlowych. Dnia 8 grudnia 2017 roku UE i Japonia zakończyły negocjacje dotyczące podpisania Umowy o Partnerstwie Gospodarczym UE - Japonia (EU-Japan Economic Partnership Agreement EPA, 2018). Mimo, że negocjacje trwały dosyć długo, bo od 25 marca 2013 roku, to obu stronom zależy na dokończeniu prac i oficjalnym jej podpisaniu (Stępień, 2014). Obu stronom zależy też na poprawie wzajemnych stosunków i stworzeniu jednej z większych w świecie strefy wolnego handlu (na miano największej strefy wolnego handlu w świecie zasługiwałaby strefa wolnego handlu UE-USA, ale negocjacje TTIP dotyczące jej utworzenia zostały zawieszone). Finalizacja negocjacji jest bowiem ważnym krokiem na drodze do wprowadzenia największej dwustronnej umowy handlowej, jaką kiedykolwiek wynegocjowała Unia Europejska. Umowa o partnerstwie gospodarczym otworzy ogromne możliwości rynkowe dla obu stron, wzmocni współpracę między Europą i Japonią w wielu dziedzinach.

Według prognoz Komisji Europejskiej, po wejściu w życie umowy zostanie zniesionych lub obniżonych $90 \%$ ceł w handlu UE - Japonia oraz zniesione zostaną bariery administracyjne, które utrudniały unijnym towarom dostęp i konkurowanie na japońskim rynku (Wnukowski, 2015). Główne elementy umowy odnoszą się właśnie do ceł. Umowa o partnerstwie gospodarczym usunie ogromną większość z 1 miliarda euro ceł płaconych rocznie przez przedsiębiorstwa UE eksportujące do Japonii, a także wiele długotrwałych barier regulacyjnych (Tarnowska, 2017). Unijne towary mogą zyskać licznych odbiorców. Wielkość japońskiego rynku to 127 milionów konsumentów. Unijni producenci towarów sektora rolnego liczą na zwiększone możliwości eksportowe.

Jak pokazano w niniejszym opracowaniu firmy z UE eksportują coraz więcej towarów a w 2017 roku eksportowały do Japonii towary o wartości ponad 60 mld euro. Umowa może wpłynąć na jeszcze większy wzrost tego eksportu. Przewiduje się, że unijny eksport do Japonii wzrośnie o 10\%, w szczególności w sektorze spożywczym (Jarco, 2017). Jest również szansa, że wzrośnie eksport polskich firm na tamtejszy rynek.

Wydaje się być szansą również dla unijnej żywności. Uzgodniony terminarz redukcji taryf przewiduje znaczne ograniczanie taryf na import europejskich serów i wina do Japonii w ciągu najbliższych 15 lat (Umowa..., 2018). Obecnie cła na sery, w tym takich jak Gouda i Cheddar wynoszą 29,8\%, a na wina średnio są na poziomie 15\%. Umowa ma również zezwolić UE na zwiększenie wywozu wołowiny do Japonii, przewiduje się bezcłowy handel przetworzonym mięsem wieprzowym i prawie bezcłowy handel świeżym mięsem wieprzowym. Umowa zapewnienia ponadto ochronę ponad 200 wysokiej jakości europejskich produktów rolnych, tzw. oznaczeń geograficznych (GI) na terenie Japonii. Wśród nich znajdują się produkty z Polski, takie jak: oscypek, rogal świętomarciński, obwarzanek krakowski czy jabłka grójeckie (Więcej..., 2017). Przewiduje także zagwarantowanie ochrony wybranych japońskich oznaczeń geograficznych w UE.

Umowa została uzgodniona ze stronami i zapisana, a po zakończeniu weryfikacji ostatecznej wersji tekstu, angielski tekst umowy zostanie przetłumaczony na pozostałe 23 języki urzędowe UE, a także na język japoński. Następnym krokiem będzie przedstawienie przez Komisję porozumienia w sprawie zatwierdzenia Parlamentowi Europejskiemu i państwom członkowskim UE. Czas wejścia w życie ustawy przewidywany jest najpóźniej do pierwszej połowy 2019 r. czyli przed końcem bieżącego mandatu Komisji Europejskiej. 


\section{Podsumowanie}

Przeprowadzona analiza skłania do sformułowania wniosków:

1. Kraje UE są liczącym producentem i eksporterem produktów żywnościowych w świecie, pogłębiona wymiana handlowa żywnością ma miejsce również z Japonią. Zarówno eksport, jak i import żywności stron rósł na przestrzeni badanych lat, zatem można domniemywać o dalszej pogłębionej wymianie handlowej. Należy zauważyć znaczący w ostatnich latach wzrost eksportu żywności z UE do Japonii.

2. Perspektywy rozwoju wzajemnej współpracy między Unią Europejską a Japonią wydają się optymistyczne. Zakończyły się negocjacje dotyczące podpisania Umowy o Partnerstwie Gospodarczym UE - Japonia. Można oczekiwać, że już w niedługim czasie powstaną nowe, korzystniejsze warunki intensyfikacji wymiany żywnością, które ułatwią handel pomiędzy stronami. Duże znaczenie dla krajów UE będzie miało otwarcie japońskiego rynku dla unijnej żywności.

3. Przeprowadzona analiza umożliwia stwierdzenie, że istotne są starania obu stron w aspekcie intensyfikacji wzajemnej współpracy.

\section{Literatura}

Aktualności. (2017). Tygodnik rolniczy (News, Agricultural weekly). Pobrano czerwiec 2018 z: http:/www.tygodnik-rolniczy.pl/articles/aktualnosci /ue-z-rekordowym-eksportem-zywnosci.

Grabowiecki, J. (2005). Przyczyny stagnacji gospodarczej Japonii (Causes of Japan's economic stagnation), Gospodarka Narodowa, 5-6, 63-83.

EU-Japan Economic Partnership Agreement (EPA). (2018). Pobrano kwiecień 2018 z: http://ec.europa.eu/trade/policy.

Extra-EU trade of food, drinks and tobacco (SITC 0+1) by partner. (2018). Eurostat. Pobrano czerwiec 2018 z: http://appsso.eurostat.ec.europa.eu/nui/submitViewTableAction.do.

Jarco, M. (2017). Lewiatan: umowa handlowa UE - Japonia przyniesie korzyści Polsce (Lewiatan: EU-Japan trade agreement will benefit Poland). Pobrano kwiecień 2018 z: https://www.bankier.pl/wiadomosc.

Barcz, J., Kawecka-Wyrzykowska, E., Michałowska-Gorywoda, K. (2016). Integracja europejska w okresie przemian (European integration in the period of change), PWE, Warszawa.

Mazur, G. (2016). Interesy ofensywne unijnych przedsiębiorstw w kontekście negocjowanej umowy o strefie wolnego handlu UE - Japonia (Offensive interests of EU enterprises in the context of the negotiated agreement on the EU-Japan free trade zone). Unia Europejska.pl, 3(238), 6-18.

Misala, J. (2011). Międzynarodowa konkurencyjność gospodarki narodowej (International competitiveness of the national economy), PWE, Warszawa.

Pasierbiak, P. (2015). Osłabienie powiązań gospodarczych Japonii z Unią Europejską w latach $2007-2014$ (The weakening of Japan's economic ties with the European Union in 2007-2014). Annales Universitatis Mariae Curie-Skłodowska. Sectio H. Oeconomia, 49(2), 127-137.

Rośnie eksport rolno-spożywczy UE. Czas na podbój Japonii (The EU' agri-food exports are growing. It's time to conquer Japan). (2017). Pobrano maj 2018 z: https:/www.money.pl/gospodarka/wiadomosci/artykul.

Stępień, S. (2014). Japonia i Unia Europejska w obliczu nowej fali liberalizacji handlu światowego (Japan and the European Union in the face of a new wave of liberalization of world trade). Politeja, Księgarnia Akademicka, Łódź.

Strzępka, K. (2017). Jest porozumienie polityczne UE z Japonią w sprawie handlu (There is an EU political agreement with Japan regarding trade). Pobrano maj $2018 \mathrm{z}$ : https://www.bankier.pl/wiadomosc.

Tarnowska, W. (2017). Zawarto porozumienie dotyczące wolnego handlu między UE i Japonią (The agreement on free trade between the EU and Japan was signed). Pobrano maj $2018 \mathrm{z}$ : http://pulsazji.pl/2017/12/20.

Total foods: EU Trade flows and balance (2018); European Union, Trade in goods with Japan; Eurostat Comext. Pobrano kwiecień $2018 \mathrm{z}$ : www.trade.ec.europa.eu/doclib/docs.

Trade flows by HS section 2013 - 2016. (2017). EU, trade with Japan. Pobrano marzec 2018 z: www.trade.ec.europa.eu/doclib/docs. 
Trade flows by HS section 2014-2017. (2018). EU, trade with Japan. Pobrano kwiecień 2018 z: www.trade.ec.europa.eu/doclib/docs

Trade Flows by SITC product grouping 2013-2016. (2017). EU, Trade with Japan; SITC Rev.3. Product Grouping. Pobrano marzec 2018 z: www.trade.ec.europa.eu/doclib/docs.

Trade Flows by SITC product grouping 2014-2017. (2018). EU, Trade with Japan; SITC Rev.3. Product Grouping. Pobrano kwiecień 2018 z: www.trade.ec.europa.eu/doclib/docs.

Trade Flows by SITC section 2013-2016. (2017). EU, Trade with Japan. Pobrano marzec 2018 z: www.trade.ec.europa.eu/doclib/docs.

Trade Flows by SITC section 2014-2017. (2018). EU, Trade with Japan. Pobrano kwiecień 2018 z: www.trade.ec.europa.eu/doclib/docs.

Umowa o wolnym handlu UE - Japonia (The EU-Japan Free Trade Agreement). (2018). Pobrano maj 2018 z: https://www.pkobp.pl/aktualnosci/aktualnosci-eksportera

Wawrzyński, P. (2013). Postdobrobyt. Przyczyny i skutki kryzysu Europy (Time after prosperity. Causes and consequences of the crisis in Europe), Wydawnictwo Von Borowiecky, Warszawa.

Więcej naszej żywności ma trafić do Japonii (More of our food is expected to reach Japan). (2017). Pobrano maj 2018 z: http://www.tygodnik-rolniczy.pl/articles/aktualnosci.

Wnukowski, D. (2015). Umowa o wolnym handlu UE - Japonia: szanse dla polskiego biznesu (EU-Japan Free Trade Agreement: opportunities for Polish business), PISM, Biuletyn, nr 27(1264), Warszawa.

Do cytowania / For citation:

Drzymała A. (2018). Handel żywnością między UE a Japonią. Problemy Rolnictwa Światowego, 18(3), 91-101; DOI: 10.22630/PRS.2018.18.3.69

Drzymała A. (2018). Food Trade EU with Japan (in Polish). Problems of World Agriculture, 18(3), 91-101; DOI: 10.22630/PRS.2018.18.3.69 